\title{
Carnivalizing the Cold War: Mexico, the Mexican Revolution, and the Events of 1968
}

Julia Sloan

\section{(2) OpenEdition}

\section{Journals}

Electronic version

URL: https://journals.openedition.org/ejas/7527

DOI: $10.4000 /$ ejas. 7527

ISSN: 1991-9336

\section{Publisher}

European Association for American Studies

\section{Electronic reference}

Julia Sloan, "Carnivalizing the Cold War: Mexico, the Mexican Revolution, and the Events of 1968", European journal of American studies [Online], 4-1 | 2009, document 1, Online since 30 March 2009, connection on 08 July 2021. URL: http://journals.openedition.org/ejas/7527 ; DOI: https://doi.org/ 10.4000/ejas. 7527

This text was automatically generated on 8 July 2021.

Creative Commons License 


\title{
Carnivalizing the Cold War: Mexico, the Mexican Revolution, and the Events of 1968
}

\author{
Julia Sloan
}

\section{Introduction}

1 During the 1960s, United States intelligence officers in communiqués back to their supervisors in Washington DC lamented that the political situation in Mexico was so complicated as to evade easy and sure comprehension. They expressed frustration and uncertainty about such things as the role of communism in Mexico, the ideology of the protest movements taking place there throughout the decade, and the difficult logic of Mexico's relationship with Cuba. ${ }^{1}$ This confusion resulted from, among other things, the profoundly different views the two nations had of the Cold War.

2 The Cold War world was governed by the bipolarity established and enforced by the United States and the Soviet Union. Within this context, the superpowers engaged in a global struggle for nothing less than "the soul of mankind," each advancing their own agendas for the betterment of all. For the United States the route to progress lay in modernization through democratic capitalism, involving bringing the world's poorer nations into the international economy and elevating the living conditions of their people. Conversely the Soviet Union similarly advanced improvements in the material quality of life for the world's poor, but through the communist system. Thus, both superpowers had essentially the same broad agenda, but diametrically opposed ideologies governing how to achieve it. Practically, however, their methods for reaching this goal were not so far apart, both involving the assertion of their military and economic power over the world's weaker and poorer nations. ${ }^{2}$

3 Mexico was one such nation. For the United States the Cold War was a global struggle against communism as embodied by the totalitarian Soviet state. The United States government and a significant portion of its citizenry considered communism an evil force in the world, one that must be combated with all available ideological, military, and financial means. Mexicans, and Latin Americans in general, on the other hand took 
a much less critical view of communism and were less likely to associate all things communist with the Soviet Union. As a result, Mexicans viewed the Cold War not as a principled crusade, but as an example of aggression by imperialist states whose financial and military power allowed them to dominate less developed countries.

4 Nonetheless, neither Mexico nor any other Third World nation could escape the Cold War and its pervasive influence, both in international affairs and in domestic politics. Thus, to fully appreciate events and developments in Mexico during the Cold War, we must understand both the foreign and domestic components involved. We must explore the relationship between the overarching ideology of the Cold War and the important national ideology of the Mexican Revolution. We must employ what one scholar of the Cold War in the Third World has called the 'double vision'. ${ }^{3}$

5 The Russian theorist Mikhail Bakhtin provides a theoretical framework through which the dynamic relationships between the superpowers and Third World nations, in this case Mexico, can be understood. Bakhtin characterizes heteroglossia as a situation in which context is more important than text. In a state of heteroglossia, the meaning of all utterances is defined by the context. ${ }^{4}$ As such heteroglossia is an apt concept for analyzing the Mexico of 1968 and, arguably, the ways in which the Cold War was experienced in the Third World in general.

6 In addition to heteroglossia, Bakhtin provides another concept useful for analyzing the Cold War in the Third World during the 1960s. Carnival or carnivalization involves the destabilization of the center, the normal, and the regular through the addition of multiple points of view. This concept illustrates the processes occurring in Mexico and throughout the Third World as countries began to contextualize the Cold War and learn how to exist, even succeed, within it. Their voices became part of the global policy discussions of the day. The resulting multivocal dialogue was at once destabilizing and complicating for the superpowers. Thus, in carnivalesque fashion, Mexico by the 1960s, had begun to reframe the Cold War not as a contest between communism and capitalism, but as a contest between the nations that were internationally dominant and those that were dominated. Taken together, heteroglossia and carnivalization posit a world in which Third World peoples appropriated the rhetoric, ideologies, and symbols of the Cold War for their own purposes. In doing so the multiplicity of texts within the Cold War context fractured the bipolarity the superpowers had worked so assiduously to maintain.

7 In this environment where bipolarity had given way to conflicting discourses and an increasingly multivocal understanding of the Cold War, Mexicans began to view the Cold War, its combatants, and its battles through the lens of their own Revolution. That Revolution, as embodied in the 1960s by its institutionalization (the ruling Partido Revolucionario Institucional or PRI) and revolutionary nationalism, was an ongoing struggle between the government and the popular classes and their advocates for control of the national agenda. The Cold War became a primary discursive arena in which this struggle was waged in the 1960s. Most prominently in the watershed year 1968, when Mexico hosted the Olympic Games and experienced its most significant social protest movement in a generation, the conflicting discourses of the Cold War took center stage. This article seeks to identify those discourses and the points at which they influenced the events of 1968.

2. The Influence of Communism 
8 The reasons for the primacy of Cold War-related discourses in Mexico in 1968 were multiple, but foremost of all was the fact that communism occupied a prominent position in the struggle between Mexican youth and their government. In a clear example of heteroglossia, the context of communist ideologies, sympathies, and allegations proved far more important than the text. A local understanding of communism won out over the global characterization advanced by the United States. In addition, US anti-communist rhetoric failed to have the desired effect in Mexico, and pro-communist positions resonated throughout Latin America for reasons that had little to do with the Cold War and much to do with regional circumstances. ${ }^{5}$

9 As one Cold War scholar has noted, "Communist Parties in Latin America and their sympathizers cannot easily be fitted into the United States State Department's kit for profiling communists." Profiling communists in Mexico would likely involve casting too wide a net due to the popular front strategy adopted by leftist parties throughout the region. As the name implies, the popular front was a coalition of organizations allied in their adherence to certain general principles but sometimes quite divergent on the specifics. Communists might ally themselves with all manner of other leftists to achieve a broad goal or advance a general agenda within a particular country, but this alliance would not necessarily equate to ideological agreement. Thus, communists in Mexico were neither the political outcasts nor the social scapegoats that they sometimes were in the United States.

10 Even when those seeking to profile communists could identify them within the popular front, the very nature of the communist agenda could prove problematic within the rigid structure of bipolarity. This is because, as Jorge Castaneda argues, for communist parties in Latin America the "long-term objective remained a national, democratic revolution, agrarian reform, and an alliance with the middle-classes and the national bourgeoisie." Such an alliance would be antithetical to strict Marxist doctrine but as Jean Franco contends, "Marx's work is often badly translated and crudely digested" in Latin America. ${ }^{7}$ This is not to suggest that Latin Americans could not accurately translate or digest Marxism, but rather that they chose to make of it what worked best for them. Here again is an example of heteroglossia.

11 The resonance of the popular front in general and communist ideas in particular in Latin America rested in the simple fact that "in Latin America, joining the Communist Party was one way of getting close to that elusive entity - the "people'." ${ }^{8}$ Because of the centrality of "the people" to the discourse of revolutionary nationalism, any political movement or organization in Mexico professing to advance their interests was likely to fall in line with the ideology of the institutionalized revolution. Protestors and politicians alike looked to "the people," both real and mythologized, for revolutionary validation and popular legitimacy.

12 The Cuban Revolution in 1959 and Fidel Castro's conversion to communism shortly thereafter brought these issues to the forefront of Mexican political discourse.

The Cuban Revolution put the Mexican government between the proverbial rock and a hard place. The rock was the United States, whose determined, public opposition to the Cuban Revolution and Castro government helped shape a decade of United States Latin American relations. The hard place was Mexican public opinion that saw in the Cuban events something akin to the Mexican Revolution of 1910-1917, and thus something positive and worthy of support. ${ }^{9}$ 
14 After Castro allied himself with the Soviet Union, the United States attempted to isolate Cuba from the community of nations. Mexico refused to sever ties with Cuba despite much pressure from and repeated efforts by the United States to expel Cuba from the Organization of American States. A 1964 vote imposed sanctions against Cuba and required all member states to comply. Mexico's ruling party, seeking to avoid "popular wrath," steadfastly refused. ${ }^{10}$

15 President Adolfo Lopez Mateos revealed the complexity of Mexico's position on Cuba when he said: "We Mexicans have, alone, accomplished our revolution, by ourselves and for ourselves. We could no longer say this about the Cuban revolution." ${ }^{11}$ With this brief statement Lopez Mateos attempted to appease the United States by condemning Cuba's affiliation with the Soviet Union while reaffirming the Mexican commitment to revolutionary nationalism; to reject communism while validating revolution. Such diplomatic and rhetorical machinations make clear the context of Mexican popular interest in Cuban communism and provide a potent example of the multi-layered significance of one of the Cold War's most contentious relationships.

16 By the late 1960s communism remained at the forefront of Mexican political discourse, but still often in heteroglossia fashion. For example, in 1968 both the student protest movement and the administration of President Gustavo Diaz Ordaz routinely invoked "the people" when asserting their revolutionary and nationalistic credentials. As the youth protest against Diaz Ordaz and his government grew larger and more vitriolic, the president worked harder to discredit it in the eyes of both foreign and domestic audiences. His key strategy for doing so was to claim communist conspiracy and foreign infiltration of the student organizations. The Diaz Ordaz Administration had some plausible evidence for making such assertions, but these claims did not have the desired effect at home or abroad. The student movement, as a popular social protest movement, ostensibly began on 26 July 1968 when two student marches collided in downtown Mexico City and erupted into a riot. ${ }^{12}$ One of the student groups was marching in protest against government violation of university autonomy and the ensuing acts of repression committed by the hated riot police, the granaderos. The other group was marching to mark the anniversary of the Cuban revolutionary attack on the Moncada Barracks. The latter group clearly had communist members and was influenced by communists. A number of student organizations at Mexico's major universities, particularly the UNAM, had communist members, ideals, or agendas. The government had for years monitored these groups and manipulated campus politics. While the conflagration on 26 July 1968 was cause for increased concern, the proCuban students' political orientation provided the government with an opportunity to deflect attention from the other group of students who expressed legitimate criticism of police repression. ${ }^{13}$

17 As the student movement continued and grew through the summer and fall, the Mexican government kept up its claims of communist agitation. Yet this explanation did not have the anticipated impact on either of the intended audiences, the Mexican public or foreign observers. Firstly, for Mexican public opinion, the communist threat was not sufficiently menacing. Communist and socialist political parties operated relatively openly in Mexico and had an influence in labor unions, on university campuses, and in intellectual and artistic circles. Secondly, even United States embassy and intelligence-gathering personnel did not accept Diaz Ordaz's claims of communist control of the student movement. This skeptical assessment from American officials, 
even in a time when State Department and Central Intelligence Agency officials could be accused of wearing rose-colored glasses given their propensity to overstate the red menace, reveals the danger in crying communist. Diaz Ordaz sought to use communist conspiracy allegations to gain political legitimacy for his repressive handling of the student movement, but instead only undermined his image among American officials. ${ }^{14}$ Justifications for rejecting the student demand to repeal the controversial Law of Social Dissolution may have been rooted in the need to protect Mexico from internal subversion, but they were highly problematic. Passed when then Senator Diaz Ordaz had led that body, this statute in the Federal Penal Code was sufficiently vague as to be widely applied and sufficiently broad as to be easily abused. The law covered any activity engaged in by an individual or group that could be deemed as threatening the social fabric of Mexico. Mexicans as diverse as striking railroad workers and the famed painter David Alfaro Siquieros as well as students in 1968 were charged and jailed under this law. ${ }^{15}$ Once again the language of the Cold War, threats of communist infiltration, and foreign subversion peppered discussions of this law and prevented its repeal, all the while reflecting the dominance of US-style rhetoric over the substance of political reality in Mexico.

18 Even as the government of President Diaz Ordaz committed its worst act of violence and repression against the student movement, it continued to allege communist conspiracy. Just hours after the brutal Tlatelolco Massacre in which a still undetermined number of civilians, most of them students, were killed, government officials made another public claim of communist infiltration and communist responsibility for the carnage of that evening. After midnight on 3 October 1968, as soldiers hosed the bloodstains from the Plaza de las Tres Culturas and ambulances and army trucks carried the bodies of the dead back to military bases, the Mexican government summoned foreign journalists to a press conference. In addition to informing these reporters that student snipers had fired the first shots and that this was a matter of national security, the government claimed that communist agitators from abroad had been responsible for the violence that had taken place. ${ }^{16}$ Here again, the Mexican government employed a rhetorical weapon of the Cold War to perpetuate a lie and justify a heinous act.

3. Politicization and Internationalization

19 Another reason why heteroglossia and carnivalization characterize the events of 1968 in Mexico and why Cold War discourses came to occupy such an important place in these events is due to what Greg Grandin has called "the politicization and internationalization of everyday life" in Mexico during this period. ${ }^{17}$ During the Cold War in Latin America, the most routine elements of national life like newspaper editorials, labor negotiations, and university curricula were dominated by the rhetoric of bipolarity. When the Cold War came to Latin America a constant, unrelenting filtering of all aspects of national life through North American and Soviet Cold War barometers began.

20 The "everyday" concept popularized by James C. Scott, and most notably applied to Mexico by Gilbert Joseph et al in Everyday Forms of State Formation, does not confine itself to the elements of life, personal or societal, that are truly mundane. Rather it also connotes those events of popular origin undertaken by "everyday" people as opposed to heads of state, captains of industry, and celebrities in artistic and intellectual life. ${ }^{18}$ Certainly the 1968 student movement was not a mundane occurrence, but it was a 
popular movement. Further it was part of a growing constellation of popular movements, including almost annual student strikes throughout the 1960s as well as protest movements launched by railroad workers, teachers, doctors, and others. The student movement was definitely undertaken by everyday people, tens of thousands of them who took to the streets to protest, hundreds of them who languished in prison for their participation, and an additional undetermined amount that died as a result of that participation. Grandin's quote suggests that the lives of everyday people, just like the actions of their governments, were politicized and internationalized. The events of 1968 did not change this, but rather revealed that Mexicans had begun to internalize this reality. The United States and the Soviet Union filtered national events for the purpose of surveillance and control. Mexicans did this as a means to advance their own agendas. ${ }^{19}$

21 Though the student movement did not succeed in taking its message directly to the people and winning their support as French students had tried to do in Paris, the Mexican youth did have an ideological affinity with certain elements of the press. This is not to say that large numbers of journalists openly praised the student cause (although some did), but rather to suggest that left-leaning editors and columnists tended to perceive Mexico's situation in much the same way the students did. Some journalists presented 'rebel without a cause' images and derided the students as lazy and spoiled at best, delinquent and subversive at worst. Countless articles about the youth problem and the generational question ran throughout the summer of 1968 in Mexico City periodicals. ${ }^{20}$

22 However, countless other articles framed Mexico's domestic situation in the context of the Cold War. These journalists, like the students, recognized the "politicization and internationalization" of their everyday lives and their country's everyday problems and controversies. In articles too numerous to list, the Diaz Ordaz Administration and the United States shared blame for many of the problems facing the nation. The war in Vietnam was the obvious focus of much of this condemnation, but the Mexican media took aim at individuals and agencies of the United States government as well. Most significantly, references to the Mexican Revolution and the institutionalized revolution (usually as being in trouble) and the Cold War (usually as being partially to blame for the trouble) worked their way into articles ostensibly about the student movement. It seemed that Mexican journalists, in their everyday coverage of the student movement, could hardly write about it without making reference to the Cold War. ${ }^{21}$ Thus they helped to popularize the politicization and internationalization of everyday life.

4. The Context of Mexican-US Relations

A third explanation of the convergence of revolutionary nationalism and the Cold War lies in the long history of Mexican relations with the United States. Looking at diplomacy, politicians on both sides of the U.S.-Mexican border had long since recognized the importance and the complexity of the relationship between their two nations. With a shared colonial past and hard-fought struggles for national independence, the doctrine of pan-Americanism had found many adherents in the late $19^{\text {th }}$ and early $20^{\text {th }}$ centuries in both countries. However, as the nature of Mexico's dependent status relative to the United States became clear, and as Mexico became embroiled in a revolution in which that dependence would be a key issue, the relationship between the two neighbors became more complex. Perceived cordial relations with the United States became a political liability for Mexican officials at 
home but a virtual necessity abroad. Militarily, the United States dominated Mexico, the United States was Mexico's most important trading partner, and a long history of cross-border migration left the populations and interests of the two nations inexorably intertwined.

24 During the 1910 Revolution, anti-Americanism became a hallmark of Mexican nationalism when militants targeted United States and other foreign investments and new laws tightened the country's hold on its natural resources and key industries. Expropriation of US-owned property, assertion of subsoil rights, and limitations on foreign ownership all framed foreign involvement in Mexico as a threat to revolutionary principles. The land and labor reforms so central to the revolutionary ideology of 1910 were substantively tied to anti-Americanism as post-Revolutionary governments took land from foreign owners and distributed it to the campesinos and as new labor laws protected workers from the exploitation they had previously suffered. It was also politically expedient for the new ruling party, which framed economic nationalism alongside land and labor reform as the third leg of the institutionalized revolution.

25 When the Cold War was in its infancy, Mexican anti-Americanism evolved from issues of expropriation, land ownership, and treatment of labor to broader issues of national sovereignty, economic nationalism, and anti-imperialism. In the 1960s, for the people in the popular front and communist organizations, "the principle enemy was once again imperialism, reduced to its barest expression, the government of the United States." 22 Among the Mexican population as a whole, the majority of people favored remaining neutral during the Cold War. ${ }^{23}$

26 As the students took on their government in 1968, the latter's relationship with the United States was of central importance. Anti-Americanism had occupied a prominent place in Mexican revolutionary nationalism since the days of the Revolution itself, but that sentiment had ebbed and flowed throughout the intervening half century. Episodes like the oil expropriation in 1938 and the nationalization of the electrical grid in 1958 sparked groundswells of anti-Americanism, as did the Cuban Revolution, Bay of Pigs invasion, and death of Che Guevara. As the latter three items suggest, popular criticism of the United States, its policies, and all it represented was on the rise in the 1960s, and was quite visible in the 1968 student movement.

27 Beyond United States guilt for the failed invasion of Cuba and complicity in the death of Che Guevara, a more generalized critique of the systemic place of the United States in the world had taken hold in Mexico in the 1960s. Mexicans, particularly those of the political left, resented American dominance in global affairs and influence in Mexico. ${ }^{24}$ Thus, the deeply rooted strain of anti-Americanism in Mexican political discourse took on new significance during the Cold War. As the students challenged their government in 1968, one example of the "primacy of context over text" comes from the student marches themselves and their tendency to make references to Che Guevara, Ho Chi Minh, and Mao Zedong in their signs, banners, and chants. Che was an iconic figure throughout Latin America, particularly after his death at the hands of United States forces in Bolivia the previous year. Ho Chi Minh and Mao Zedong were similarly symbolic but perhaps less understood in Mexico. Thus, when the students carried pictures of Che Guevara and chanted Mao-Mao-Mao-Zedong as they marched through the streets of Mexico City during their protests, the context of these figures was far more important than the texts of their lives and their ideologies. These men were 
symbols of defiance, independence, and resistance, in the case of Che and Ho Chi Minh, against the United States. When the students made reference to them, the message was not one of ideological solidarity with Cuban, Vietnamese or Chinese communism, but rather unity in the struggle against domination.

Tens of thousands of Mexican youth participated in rallies and marches in the summer and fall of 1968, and while certainly a portion of them knew and agreed with the ideological texts of these revolutionaries, the vast majority just knew that they were revolutionaries. And to be a revolutionary in Mexico had, for decades, been looked upon favorably as advancing the cause of the downtrodden, fighting for independence, and standing up to imperialist powers like the United States. Thus, the importance of these figures and the use of their images and names in the protests of 1968 lies not in their value as text, but as context. The students lauded them for revolting against the US-dominated status quo, asserting their independence from American domination, and standing up for the weak in the face of American strength. ${ }^{25}$

5. Conclusion

While scholars provide far more eloquent explanations, the old cliché that all politics are local ultimately proves illusory. Mexicans viewed the events of the Cold War, internalized them, and came to understand them as related to their own history and particularly their revolution. The Cold War was an all-encompassing international ideology. The Mexican Revolution was an all-encompassing domestic ideology. Both were pervasive throughout politics, economics, society, and culture, becoming explanatory discourses in the process. Both provided legitimacy to their adherents and were delegitimizing for those in opposition.

30 As President Diaz Ordaz and Mexico's youth were locked in conflict to determine the meaning of that revolution and the character of the national agenda for the future, the Cold War was the arena in which they waged this battle. Three factors contributed to the centrality of the Cold War in 1968 Mexico. First, the juxtaposition of the aggressive anti-communist stance of the United States with the more tolerant and more fluid understanding of communism in Mexico made identifying communists a politically expedient move. In Mexico, politicos quickly learned that labeling an individual or group as communist was sure to raise suspicion and even contempt for them. Thus, when Diaz Ordaz was looking to discredit the student movement in 1968, labeling them as communist and raising the specter of a communist threat to the stability of Mexico seemed a likely way to win support from the United States, other members of the international community, and certain sectors of the Mexican population for repressing the students. Unfortunately for Diaz Ordaz however, the communist label did not produce the desired results. Few either at home or abroad took the threat seriously enough to act upon it. As it turned out, Diaz Ordaz was right about the global context, but wrong in assuming that this context could overcome the local text that rejected his notion of communist control of the student movement.

31 The second factor, "the politicization and internationalization of everyday life" similarly brought the Cold War more prominently into Mexican politics. The filtering of national life to express its Cold War significance effectively carnivalized the Cold War by assigning so many issues a Cold War significance and thus bringing so many people into Cold War debates. Bipolarity gave way to a multiplicity of voices and viewpoints coming out of the Third World and demanding acknowledgement. In 1968 Mexico, the press played an integral role in this "politicization and 
internationalization" across the Mexican political landscape, most prominently on issues related to the student movement. The press, particularly that on the left, routinely framed the student rebellion and politics in general within the context of the Cold War.

32 The third and final factor in making the Cold War a primary discursive arena for the contest between the students and the government was anti-Americanism. Mexico had a long history of anti-Americanism, the context of which had little to do with the Cold War prior to the 1950s. Thus, when the students marched in the streets carrying signs of Che Guevara or chanting Ho-Ho-Ho-Chi-Minh, theirs was not solely a display of solidarity with the peoples of Cuba and Vietnam, but rather a declaration of support for revolution, independence, and anti-imperialism. Neither did this represent acceptance of Soviet, Cuban, or Southeast Asian communism, but instead acceptance of Third World economic nationalism and national sovereignty. The youth were embracing anti-American symbols and in so doing, in 1968, in the height of the Cold War, elevating national issues to become international Cold War debates.

These Mexican Cold War narratives included a position on communism which evolved throughout the decade, from the early 1960s when being labeled a communist was a political liability, to the late 1960s when governmental attempts to similarly label the student movement failed. These narratives also included a strong anti-American and anti-imperialist stance, both of which had their roots in Mexican revolutionary nationalism and the long history of United States-Mexican relations. In each of these cases, domestic, revolutionary ideologies became the lenses through which Cold War issues and events were filtered. More importantly, they became arenas in which Mexican nationalists and proponents of the institutionalized revolution could prove themselves. By 1968, this pattern was well established. The ideological impact of the Cold War had already become such a part of the Mexican political landscape when the student movement began that it was already inseparable from the events themselves. Mikhail Bakhtin provides us useful theoretical tools with which to come to an understanding of the integration of the Cold War into national life at all levels and with varying degrees of significance. The expansion of Cold War understanding and debate that such integration precipitated served to carnivalize the Cold War, transforming it from mere bipolarity into the complex cacophony of influences that it clearly was by 1968. Further, heteroglossia serves to bridge the analytical gap between the macro and micro-level workings of the Cold War, between the overarching ideologies and agendas and the everyday events and attitudes. We know 1968 changed nations as well as the international milieu in which nations operated. We know that 1968's legacy is at once profound and nebulous. This application of theory to the events of 1968 in one country is meant to serve as an example of how research that seeks to integrate the national and the international, the ideological and the practical might be undertaken. The three issues in the Mexican case (the different understandings of communism, the convergence of the everyday and the local with the significant and the global, and the impact of long-standing pre-Cold War factors) serve as points of departure for further research. In this way a truly global understanding of a watershed year like 1968 may be gradually put together.

Julia Sloan, Assistant Professor of Social Science / History, Cazenovia College, Cazenovia, NY 


\section{NOTES}

1. United States officials monitored any and all communism-related items in Mexico with great interest and considerable concern. Difficulties arose, however, concerning the identification of communists and when the motivation for a particular statement, action, or event could be deemed to be 'communism'. For example, U.S. officials paid close attention to the actions of former Mexican President Lazaro Cardenas and appeared to have difficulty reconciling his nationalist, populist persona with his association with known communist organizations and sympathizers. For examples of U.S. commentary on communism in general and Lazaro Cardenas in particular, see Department of State Telegram, 2 August 1968, POL 23-8 Mex, POL 13-2 Mex, Box 2340; Department of State Airgram 27 June 1964, POL 14 Mex, POL 6 Mex, Box 2344; Department of State Airgram 17 February 1965, POL 6 Mex, Box 2344, Department of State Airgram 27 June 1964, POL 2-1 Mex, Box 2344, all in Record Group 59, National Archives, College Park (hereafter RG 59, NA). The communist question would remain prominent throughout the decade and particularly during the 1968 student movement when embassy communiqués routinely contradicted themselves about the role of communists in the movement. On numerous occasions consular officials reported Mexican government and/or press assertions of communist involvement, only to follow them up with analysis questioning the validity of these reports. Words like "scapegoat" appear in the correspondence as U.S. officials criticized the Diaz Ordaz government's handling of the student crisis. For examples of such analysis, see Covey T. Oliver to the Secretary of State, September 20, 1968, POL 23-8 Mex, Box 2340; Department of State Intelligence Note, September 26, 1968, POL 13-2 Mex, Box 2340; Department of State Telegram, 2 August 1968, POL 23-8 Mex, Box 2340, RG 59, NA. In addition to being uncertain about the communist involvement in the movement, U.S officials were wrong about the students on several other counts as well. Most significantly, after the Paris Spring when the State Department questioned whether other countries could experience a similar student uprising, the Mexican Embassy staff said no. In their analysis, undertaken in late spring and early summer of 1968 , serious conflict similar to the French situation was at least two years off and would not occur before President Diaz Ordaz left office. Within two months, the embassy would have to acknowledge that a crisis akin to that in France was not only possible in Mexico, but underway. Other, more minor miscalculations suggest an overall intelligence failure, such as when at the end of September the embassy reported a calming of tensions between students and the government and cautiously projected an optimistic resolution to the conflict. Less than a week later, U.S officials would be reporting on the carnage at Tlatelolco. See Department of State Telegram 6 July 1968, POL 13-2 Mex, Box 2340; Department of State Telegram, 14 June 1968, POL 15 Mex, Box 2341; Department of State Telegram 29 September 1968, POL 13-2 Mex, Box 2340, RG 59, NA. Finally, Mexico's relationship with Cuba remained of constant interest to the United States throughout the 1960s. For examples of U.S. analysis of that relationship, see Department of State Telegram 29 September 1969, POL Cuba-Mex, Box 2336; Foreign Service Despatch No. 1101, March 30, 1961, Amembassy, Mexico, D.F. to Department of State, Box 1511, RG 59, NARA. 
2. Melvyn P. Leffler, For the Soul of Mankind: The United States, the Soviet Union, and the Cold War (New York: Hill and Wang, 2007); Odd Arne Westad, The Global Cold War (Cambridge: Cambridge University Press, 2007).

3. Arif Dirlik, 'The Third World in 1968,' in Carole Fink, Phillip Gasser, and Detleff Junker, 1968 The World Transformed (Washington, D.C., The German Historical Institute and Cambridge University Press, 1998): 295-317.

4. Utterances herein will not be confined to the verbal, but will also be taken to include written text, visual images, government policies, and symbolic actions taken by groups or individuals. See Robert Bennett, 'National Allegory or Carnivalesque Heteroglossia? Midnight's Children's Narration of Indian National Identity,' in Barry A. Brown et al (eds.) Bakhtin and the Nation (Lewisburg, PA: Bucknell University Press, 2000): 177-194; Katerina Clark and Michael Holquist, Mikhail Bakhtin (Cambridge: Harvard University Press, 1984), 295-302; Mikhail M. Bakhtin, Rabelais and His World, trans. Helene Iswolsky, (Bloomington: Indiana University Press, 1993); Mikhail M. Bakhtin, Problems of Dostoevsky's Poetics, ed. Caryl Emerson. (Minneapolis: University of Minnesota Press, 1984).

5. Jean Franco The Decline and Fall of the Lettered City: Latin America in the Cold War (Cambridge: Harvard University Press, 2002): 60.

6. Ibid., 60.

7. Ibid.,60, 59 .

8. Ibid., 66 .

9. With his quote "Poets may see the world in a grain of sand... but only diplomatic historians could reduce the Latin American Cold War to a Cuban beach" Greg Grandin warns of the danger in placing too much emphasis on Cuba. For Mexico however, an emphasis on Cuba is warranted. Joseph, In from the Cold, 9; Angel Gutierrez, Lazaro Cardenas Y Cuba (Ciudad Universitaria, Morelia, Michoacan: Universidad Michoacana De San Nicolas De Hidalgo, Instituto De Investigaciones Historicas, 1989). Thomas C. Wright, Latin America in the Era of the Cuban Revolution (New York: Praeger, 1991): 41. 10. The first United States attempt came in January 1962 at Punta del Este, Uruguay. With Mexico's no vote and abstentions from Argentina, Brazil, Chile, and Ecuador, the United States did not have the necessary votes to remove Cuba. By 1964 however, with Argentina, Brazil, and Ecuador ruled by military regimes, the vote carried despite no votes from Mexico, Bolivia, Chile, and Uruguay. Wright, Latin America, 41, 65; Lorenzo Meyer, The Course of Mexican History (Oxford: Oxford University Press, 1991): 658. 11. For information on the position of the Lopez Mateos Administration, see 'Ponencia al Comite Directivo Nacional,' GD 304, AGN, and 'Joint Weekly No. 13,' Foreign Service Despatch no. 1101, AmEmbassy Mexico, March 30, 1961, Box 1511, RG 59, NARA 12. While the 1968 student unrest grew out of the July 26 melee and the events of preceeding days, student protest had become virtually endemic in Mexico during the 1960s. For more than a decade and across the country, student unrest had been commonplace. Thus, the 1968 movement was part of a much larger wave of youth activism in Mexico. For example, between 1963 and mid 1968 alone there were 40 episodes of student unrest that the U.S. State Department considered "significant." See Department of State Airgram no. A-1471, November 3, 1968, POL 13-2 Mex, Box 2340, RG 59, NARA.

13. Donald J. Mabry, The Mexican University and the State: Student Conflicts, 1910-1971 (College Station: Texas A\&M University Press, 1982). 
14. Philip Agee, Inside the Company (Harmondsworth: Penguin, 1975); Department of State Telegram 2 August 1968, and Department of State Memo to Secretary of State from Covey T. Oliver, August 28, 1968, POL 23-8 Mex, Box 2340, RG 59, NARA

15. 'Estos Son Los Agitadores!' Hoy, No. 1475 (17 August 1968): 18-25.

16. Christopher Brasher, Mexico 1968: A Diary of the XIXth Olympiad (London: Stanley Paul, 1968).

17. Greg Grandin as cited in Gilbert M. Joseph, 'What We Now Know and Should Know: Bringing Latin America More Meaningfully into Cold War Studies,' in Gilbert M. Joseph and Daniela Spenser (eds.) In from the Cold: Latin America's New Encounter with the Cold War (Durham: Duke University Press, 2008): 4.

18. James C. Scott, Weapons of the Weak: Everyday Forms of Peasant Resistance (New Haven: Yale University Press, 1985); Gilbert M. Joseph and Daniel Nugent (eds.), Everyday Forms of State Formation: Revolution and the Negotiation of Rule in Modern Mexico (Durham: Duke University Press, 1994).

19. Carole Fink makes a similar argument; stating 1968 represented a key phase in the Cold War when a "peculiar linkage between domestic and international affairs" emerged "between social and cultural developments, on the one hand and world politics, on the other."Carole Fink, Phillip Gasser, and Detleff Junker, 1968 The World Transformed (Washington, D.C., The German Historical Institute and Cambridge University Press, 1998): 2.

20. Leopoldo H. Mendoza, 'Mexico Y Sus Jovenes,' Hoy, No. 1422 (8 August 1966): 52-53; Ricardo Ampudia M., "Responsabilidad De La Juventud Mexicana,” Hoy, No. 1473 (20 July 1968): 18.

21. Examination of a variety of Mexico City newspapers and magazines from the summer and early fall of 1968 provide many examples of the trends discussed herein. In particular, see Siempre! and Politica.

22. Franco, The Rise and Fall of the Lettered City, 60.

23. Seth Fein, 'Producing the Cold War in Mexico: The Public Limits of Covert Communications,' in Joseph, In from the Cold, 171-213. As many as 71 per cent of Mexicans favored neutrality during the Cold War.

24. See Westad, The Global Cold War for a general discussion on political attitudes in the Third World.

25. Ibid., 158. The United States government recognized this and diplomatic correspondence between the American embassy and the Department of State makes repeated reference to the importance of revolutionary nationalism. One example of such correspondence is Department of State Airgram A-1471, November 3, 1968, POL 13-2 Mex, Box 2340, RG 59, NA.

\section{AUTHOR}

\section{JULIA SLOAN}

Julia Sloan, Assistant Professor of Social Science / History, Cazenovia College, Cazenovia, NY 